\title{
DEVELOPMENT AND PERFORMANCE OF THE ELDERLY CARE SYSTEM IN THE PEOPLE'S REPUBLIC OF CHINA
}

Yuebin Xu

NO. 36

ADB EAST ASIA

August 2021

WORKING PAPER SERIES 

ADB East Asia Working Paper Series

\section{Development and Performance of the Elderly Care System in the People's Republic of China}

Yuebin Xu

No. 36 | August 2021
Yuebin Xu is Professor at the Institute of Advanced Studies in Humanities and Social Sciences, Beijing Normal University.

This paper was prepared as a background paper to "Poverty, Vulnerability, and Fiscal Sustainability in the People's Republic of China" under TA 8997-PRC: Promoting Partnerships for South-South Cooperation II. 
(C) 2021 Asian Development Bank 6 ADB Avenue, Mandaluyong City, 1550 Metro Manila, Philippines

Tel +632 8632 4444; Fax +63286362444

www.adb.org

Some rights reserved. Published in 2021.

Publication Stock No. WPS210303-2

DOI: http://dx.doi.org/10.22617/WPS210303-2

The views expressed in this publication are those of the authors and do not necessarily reflect the views and policies of the Asian Development Bank (ADB) or its Board of Governors or the governments they represent.

ADB does not guarantee the accuracy of the data included in this publication and accepts no responsibility for any consequence of their use. The mention of specific companies or products of manufacturers does not imply that they are endorsed or recommended by ADB in preference to others of a similar nature that are not mentioned.

By making any designation of or reference to a particular territory or geographic area, or by using the term "country" in this document, $A D B$ does not intend to make any judgments as to the legal or other status of any territory or area.

This work is available under the Creative Commons Attribution 3.0 IGO license (CC BY 3.0 IGO)

https://creativecommons.org/licenses/by/3.0/igo/. By using the content of this publication, you agree to be bound by the terms of this license. For attribution, translations, adaptations, and permissions, please read the provisions and terms of use at https://www.adb.org/terms-use\#openaccess.

This CC license does not apply to non-ADB copyright materials in this publication. If the material is attributed to another source, please contact the copyright owner or publisher of that source for permission to reproduce it. ADB cannot be held liable for any claims that arise as a result of your use of the material.

Please contact pubsmarketing@adb.org if you have questions or comments with respect to content, or if you wish to obtain copyright permission for your intended use that does not fall within these terms, or for permission to use the ADB logo.

Corrigenda to ADB publications may be found at http://www.adb.org/publications/corrigenda.

Notes:

In this publication, "\$" refers to United States dollars, "CNY" to yuan, "¥" to yen, and "W" to won.

ADB recognizes "China" as the People's Republic of China and "South Korea" as the Republic of Korea.

The ADB East Asia Working Paper Series is a forum for stimulating discussion and eliciting feedback on ongoing and recently completed research and policy studies undertaken by the East Asia Department of the Asian Development Bank (ADB) staff, consultants, or resource persons. The series deals with key economic and development problems, as well as conceptual, analytical, or methodological issues relating to project/program economic analysis, and statistical data and measurement. The series aims to enhance the knowledge on Asia's development and policy challenges; strengthen analytical rigor and quality of ADB's country partnership strategies, and its subregional and country operations; and improve the quality and availability of statistical data and development indicators for monitoring development effectiveness.

The ADB East Asia Working Paper Series is a quick-disseminating, informal publication whose titles could subsequently be revised for publication as articles in professional journals or chapters in books. The series is maintained by the East Asia Department. 


\section{CONTENTS}

TABLES vi vi vis

ABBREVIATIONS vii

ABSTRACT

$\begin{array}{ll}\text { I. INTRODUCTION } & 1\end{array}$

II. SOCIAL SECURITY POLICIES FOR THE ELDERLY 1

A. International Practices in Pension $\quad 2$

(i) The Republic of Korea $\quad 2$

(ii) Japan 3

B. International Practices in Social Assistance 4

C. The PRC's Experience in Pension $\quad 5$

D. The PRC's Experience in Social Assistance $\quad 6$

III. DEVELOPMENT OF THE ELDERLY CARE SYSTEM 7

$\begin{array}{ll}\text { A. The Three-Tiered System } & 7\end{array}$

B. Residential Care $\quad 8$

C. Home and Community-Based Care $\quad 9$

D. Health and Care Integration $\quad 10$

E. Involvement of the Private Sector $\quad 11$

F. Financing $\quad 12$

IV. PERFORMANCE OF THE ELDERLY CARE SYSTEM

A. Current Demand for Residential Care is Low $\quad 15$

B. Home- and Community-Based Care is Generally Underdeveloped 17

V. KEY POLICY RECOMMENDATIONS

A. Improve the Elderly Care System for Better Integration of Residential Care 18 and Home- and Community-Based Care

B. Increase the Role of Government in Financing 18

C. Support Community and Nonprofit Organizations in providing Home- and 19 Community-Based Care

D. Support the Development of Elderly Care Management Tools 20

E. Strengthen the Role of Street Office or Township Aging Offices 20 


\section{TABLES}

1 Subsidies for Private Elderly Care Facilities in Hangzhou and Wuhan, 2018

2 Subsidies for Elderly Care Service Users in Chengdu and Wuhan 


\section{ABBREVIATIONS}

$\begin{array}{ll}\text { APSD } & \text { Assistance for People with Special Difficulties } \\ \text { CNCA } & \text { China National Committee on Aging } \\ \text { EPI } & \text { Employee's Pension Insurance } \\ \text { UEBPS } & \text { Urban Employees' Basic Pension System } \\ \text { HCBC } & \text { Home- and community-based care } \\ \text { LTCI } & \text { Long-term care insurance } \\ \text { MOCA } & \text { Ministry of Civil Affairs } \\ \text { NPI } & \text { National Pension Insurance } \\ \text { NDRC } & \text { National Development and Reform Commission } \\ \text { PRC } & \text { People' Republic of China } \\ \text { PSD } & \text { People with Special Difficulties } \\ \text { RBPS } & \text { Residents Basic Pension System } \\ \text { ROK } & \text { Republic of Korea }\end{array}$




\begin{abstract}
This study describes the development and performance of the emerging elderly care system in the People's Republic of China and provides policy recommendations. In the past two decades, the PRC developed a three-tiered elderly care system consisting of "home-based care as core support, community-based care as necessary support, and residential care as supplementary support." This has been operated with increasing involvement of the private sector with subsidies by the government. The study finds that the demand for residential care is low due mainly to availability of family care and unaffordability for care services, and home- and community-based care are generally underdeveloped, providing mainly amenities for recreational activities and limited care services. The study proposes that the current elderly care system be improved for integrated and balanced development of home- and community-based care and residential care, and the government increase its financing role to enable those with care needs to access services, among others.
\end{abstract}




\section{INTRODUCTION}

The People's Republic of China (PRC) became an aging society in 2001 when the number of people over age 65 reached 90.62 million or $7.1 \%$ of the population. By 2019, its population over the age of 65 had grown to 176.03 million or $12.57 \% .^{1}$ It is projected that the PRC will move to an aged society by 2027 when 14\% of the population will be aged 65 and older. ${ }^{2}$ The China National Committee on Aging (CNCA) projected that the population over age 65 will reach over 400 million by 2035, accounting for more than $30 \%$ of the population. ${ }^{3}$

In the early 2000s, the major efforts of the government in addressing population aging were focused on the establishment of social security systems and expanding their coverage such as pensions and medical care insurance, and social assistance was designed as a safety net for families falling into poverty. It was not until the early 2010s when increasing emphasis began to be placed on the development of an elderly care system. As a developing and middle-income economy, the phenomenon of rapid population aging in the PRC has been often discussed in terms of "aging before getting rich". In this context, the provision of affordable care services for both the government and older people has been a major issue for the government in developing the elderly care system.

This study attempts to understand the development and performance of the emerging elderly care system in the PRC and provide policy recommendations. Section 2 provides a brief account of the major income security policies and medical care insurance that are related to the elderly population. Section 3 sets out an overview of the development of the three-tiered elderly care system focusing on describing the main policies and progress of the system. Section 4 presents findings from surveys and qualitative studies in several cities of the PRC, which may reflect the operation of the elderly care system. Section 5 provides policy recommendations.

\section{SOCIAL SECURITY POLICIES FOR THE ELDERLY}

Social security policies for the elderly include mainly pensions and social assistance, which aim to provide adequate retirement incomes for the elderly to maintain quality of life and prevent poverty in old age. Pensions are typically funded by contributions made by employees and employers, and sometimes with subsidies from the government. Social assistance refers to government-funded cash or in-kind benefits provided to people usually meeting a set of means-test criteria. Internationally, while the pension systems in most countries have been undergoing active reforms to improve financial sustainability and increase coverage due to population aging, social assistance has received increasing attention in both developed and developing countries as a device to address poverty and security gaps left out by social insurance. ${ }^{4}$

\footnotetext{
NBS. 2021. http://data.stats.gov.cn (accessed February 2021).

2 World Bank. 2018. Options for Aged Care in (the People's Republic of)China: Building an Efficient and Sustainable Aged Care System.

3 China National Committee on Aging (CNCA), 2010, "China's population is rapidly aging and the aging process is irreversible", http://www.cncaprc.gov.cn/llxw/391.jhtml.

4 Organisation for Economic Co-operation and Development (OECD). 1999. The Battle Against Exclusion, Social Assistance in Canada and Switzerland. Paris; K. Subbarao et al. 1997. Safety Net Programs and Poverty Reduction: Lessons from Crosscountry Experience. Washington, DC: The World Bank.
} 
In countries where long-term care insurance is not implemented, such as in the PRC, pensions and social assistance are often the major sources of income for the elderly to access elderly care services. This section first presents an overview of international practices in financing social security for the elderly with a focus on the pension system and major social assistance programs in the Republic of Korea (ROK) and Japan, and then provides a brief account of the PRC's major social security programs relating to the aged population.

\section{A. International Practices in Pension}

Most of the pension plans in the world fall broadly under two types according to financing methods: defined benefit and defined contribution plans. In a defined benefit plan, a worker reaching retirement age is paid with a predefined amount of pension benefits usually linked with the wage level and number of years contributed to the plan. Defined benefit plans are often unfunded, such as the pay-as-you-go scheme in which current pensions are covered by taxes of the current workforce, usually with a reserve established to help even out imbalances between revenue and expenditure that may occur due to changes in demographic or employment patterns. In a defined contribution plan, a worker is required to pay a percentage of his earnings into an individual account that are invested in the financial markets, and is paid with the accumulated amount earned over time upon retirement. Unlike defined benefit plans, defined contribution plans do not promise a specific benefit amount. The amount of money a worker will get depends on how well the investment performs.

Pension plans can be either publicly or privately run. Most of the pension plans in the world are publicly run in that government enforces participation and contribution rates through legislation, and government may either directly manage pension funds-as in the PRC and Singapore-or contract out funds management to private companies such as in Chile and Hong Kong, China. Variations can be found between the two modes of operation such as in some Latin American countries, where the government mandates the amount of money to be saved, while the worker is left to select a pension fund on his own for enrollment.

Each country has its own unique set of pension systems tailored to the country-specific conditions. In many countries, three types of pension systems are commonly found to exist side by side targeting different segments of the population: occupational pension for people with employment, national or government pension for civil servants or other special citizens, and social pension for old people. Among them, occupational pension is often funded by contributions by employers and employees, varying across countries in terms of the proportion paid by the two parties and benefit levels. Government and social pension plans are either noncontributory and financed solely by government revenue or jointly by the government and the insured. In addition, various tax-favored individual or corporate pension plans are available as a supplement to public systems.

\section{(i) The Republic of Korea}

The ROK has four public pension systems, the National Pension Scheme (NPS), special occupational pension (SOP), basic old-age pension, and retirement allowance. NPS was established in 1988 and over the years has expanded coverage to the entire working population in the ROK except those covered under SOP. It is a defined-benefit system with employers and employees equally contributing $4.5 \%$ of wages. ${ }^{5}$ An insured worker reaching the age of 61 years is eligible for pension payment after contributing for a minimum of 10 years. A reduced early pension can be withdrawn from age 56 . Beginning in 2033,

5 OECD. 2019. OECD Pensions at a Glance 2019. https://www.oecd-ilibrary.org/docserver/b6d3dcfc-en.pdf?expires=15914 10905\&id=id\&accname=guest\&checksum=2E190B70CFBA4FCF2A2A1C1713D04AAB (accessed June 2020). 
the normal pension age will be gradually increased to age 65 , and the early pension age will also increase from 56 years to 60 years. Pension benefits are earnings-related based on both individual earnings and average earnings of all participants. To strengthen the scheme's financial sustainability, the National Pension Reform in 2007 began to reduce the replacement rate after 40 years of contributions by $0.5 \%$ for each year from 2008 , to reach $40 \%$ by $2028 .{ }^{6}$

The Basic Old-Age Pension was introduced in 2007 to mitigate poverty of old persons who had no opportunity to join NPS. The scheme is financed with general tax revenues shared between the central and different levels of local governments. People aged 65 or above who meet income and asset criteria are eligible for pension benefits, which are determined based on an average monthly income of the NPS participants over the past 3 years. Pension benefits have increased annually, and the benefit amount applied from April 2012 to March 2013 was 95,000 Korean Won (KRW) for a single household, and KRW151,000 for married couples, considering the differences in living expenses between singles and married couples. The number of beneficiaries increased from 2.9 million in 2008 to 3.8 million in 2011. ${ }^{7}$

The special occupational pension includes three independently funded and managed pension schemes covering civil servants, soldiers, and private school teachers and professors, which comprise $4 \%$ of the working-age population. These schemes operate according to the pay-as-you-go principle, with government and employees equally contributing $8.5 \%$ of the wage. Pension benefits are earnings-related and generous compared to NPS, with replacement rates reaching $70 \%$ after 30 years of contributions. Due to growing pension deficits, the three schemes are relying increasingly on government funding and are generally regarded as in need of reforms. ${ }^{8}$

Retirement allowances include a mandatory retirement allowance scheme called the severance pay system and the corporate pension system. The severance pay system was enacted in the early $1950 \mathrm{~s}$ covering all companies with five or more employees and is financed with employers contributing $8.3 \%$ of the wage. Workers are entitled to the pension after more than 1 year of continuous service, and benefits are typically paid out as lump sums equivalent to 1 month of the base wage (an average of wages for 3 months before retirement) for each year of service. Companies running the schemes are eligible for tax benefits. ${ }^{9}$ The corporate pension system was introduced in 1997 and operates as a voluntary scheme. Companies and employees are free to choose either a defined contribution or defined benefit plan, which can be managed by a separate trust such as a bank or insurance company. Pension is paid at age of 55 after a minimum of 10 years of enrollment (footnote 9 ). Apart from the above plans, individual saving plans are also encouraged through various tax concessions.

\section{(ii) Japan}

Japan has two main public pension systems, the Employee's Pension Insurance and the National Pension Insurance (NPI). The Employee's Pension Insurance was established in 1941 and NPI in 1961, covering all workers in Japan. Apart from the two public pension systems, there are also private pension plans that operate on a voluntary basis.

6 OECD. 2017. Pensions at a Glance 2017: Country Profile-Korea. http://www.oecd.org/els/public-pensions/PAG2017country-profile-Korea.pdf.

7 Yun, Sukmyung. 2015. SDD-SPPS Project Working Papers Series: Income Security for Older Persons in the Republic of Korea. Bangkok: UNESCAP.

8 H. Moon. The Korean Pension System: Current State and Tasks Ahead. http://www.oecd.org/finance/private-pensions/ 2763652.pdf.

9 AskKoreaLaw. A Guide to Severance Pay under Korean Law. https://askkorealaw.com/2020/02/12/korea-severance-pay/ (accessed June 2020). 
The Employee's Pension Insurance covers all full-time employees and part-time employees with working hours being more than $75 \%$ that of full-time workers. All employers with at least five regular workers are covered by the scheme, which is funded by contributions shared equally between employers and employees. In 2018, employers and employees each contributed $9.15 \%$ of the standard monthly wages. ${ }^{10}$ The benefits of the system include old-age pension, disability pension, and survivor's pension, which are automatically linked to changes in the consumer price index. The old-age benefit is payable when an insured reaches 65 years, and the amount is linked to both contributions and length of employment. Disability pension is paid in lump sum, also based on insurance premium and length of contribution period plus the degree of disability; while survivor's pension is paid to the surviving family if the insured dies during the insured period.

The NPI covers all people aged 20-59 years who reside in Japan regardless of nationality or length of stay, including farmers and other self-employed workers, workers in small firms with less than five regular workers, among others. NPI is a basic income scheme funded jointly by government revenues and individual contributions. Government provides $50 \%$ of the funds, while it collects a flat rate of premiums from participating individuals. Between 2015 and 2019, the amount of monthly individual contribution changed slightly ranging from 15,590 Japanese Yen (JPY) to JPY16,490. ${ }^{11}$ Benefits include a flat-rate basic old-age pension and benefits for disability or death. Pension benefits are payable when a participant reaches 65 years and has contributed for a minimum of 10 years. A full basic pension benefit requires 40 years of contribution. Benefits are adjusted proportionally for the length of contribution periods, which are indexed to net wage until the pensioner reaches 67 years, and price indexed after age 68. The full annual basic pension benefit for 2018 was equal to JPY779,300. ${ }^{12}$

\section{B. International Practices in Social Assistance}

Like pension systems, each country has a unique set of social assistance systems, which are the result of influence by many factors such as the national values, economy, and the overall social security system, among others. Typically, social assistance is means-tested and need-oriented public cash transfer to individuals or families with the aim to ensure a minimum level of basic living. A wide range of variations can be found in terms of eligibilities, benefit levels, and conditions attached to the receipt of benefits.

In recent years, the government-funded, noncontributory old-age social pension, for instance, which is a variant of social assistance specially targeted to older people, has been introduced in an increasing number of countries to address the gap in pension coverage because the social insurance systems and benefits cannot fully cover the elderly people or their special needs. ${ }^{13}$ One frequently cited example of such systems is South Africa's social pension for older people (Older Person's Grant), which provides basic pension allowances to older people above 60 years living in poverty. Combined with other categorical social assistance programs such as child support grant, disability, and foster care grant, the program has not only reduced incidence of elderly poverty but also contributed greatly to raising the standards of living of the whole family. More importantly, the scheme has also helped in promoting human capital investment in the household: with increased income in the family, children are less likely to work and more likely to go to school, children's health and nutrition status has also improved markedly, and women are more likely to be employed or to participate in the labor force. ${ }^{14}$

10 Japan External Trade Organization. 4.9.5 Employees' Pension Insurance. https://www.jetro.go.jp/en/invest/setting_up/ section4/page9.html (accessed June 2020).

11 https://www.japanistry.com/the-pension-system-in-japan/, accessed June 2020.

12 OECD. 2019. Pensions at a Glance 2019: Country Profile-Japan. http://www.oecd.org/els/public-pensions/PAG2019country-profile-japan.pdf.

13 World Bank. 2018. The State of Social Safety Nets 2018. https://www.worldbank.org/en/topic/socialprotectionandjobs/ publication/the-state-of-social-safety-nets-2018.

14 International Labour Organization. Older Person's Grant: South Africa. https://www.social-protection.org/gimi/Ressource PDF.action?ressource.ressourceld=53790. Geneva: Social Protection Department. 
The ROK's National Basic Livelihood Security Scheme, for instance, is a safety net program providing comprehensive support to poverty-stricken people. It was established in 2000 replacing a categorical social assistance scheme targeted only to people unable to work, such as the elderly, children, and the disabled. The scheme is eligible for all people with income and assets falling below national minimum living standards, and it provides a minimum level of income and services for them to maintain an acceptable standard of living. Means-test applies not only to income and assets of the individual applicant, but also to the resources or the supporting ability of parents and children. Benefits include basic living allowance and benefits in housing, education, medical care, childbirth, and funeral service. The total amount of benefits is determined as the difference between the national minimum living standards and incomes and assets of the means-test unit, excluding benefits for funeral service and childbirth. The scheme is funded mainly by the central government, which covers $80 \%$ of the funds, while local governments are responsible for the remaining $20 \% .^{15}$

Japan has one of the most developed welfare systems in the world. It has two major social assistance schemes, one providing income assistance for the poor and the other targeted specifically to various disadvantaged groups including the elderly, children, people with disabilities, and single mothers. The schemes work together to guarantee a minimum standard of living for the needy population, which is defined by the municipal governments. For instance, the amount of the minimum standard for an elderly person between 65 and 69 years old living in Tokyo in 2018 was JPY954,600 per person per year, excluding benefits in housing, medical care, and other benefits. ${ }^{16}$

\section{The People's Republic of China's Experience in Pension}

The PRC's social security policies for the elderly include pensions and social assistance. Shortly after economic reforms in the early 1980 s, the old-age pension system began to be reformed and implemented as a major policy in providing social security for the elderly population. The emergence of poverty in the mid-1990s left many people with no access to social insurance protection. Toward the end of the 20 th century, the attention of the government was drawn to social assistance to address poverty among people not covered by social insurance.

The basic pension system includes two schemes based on occupational status. One is Urban Employees' Basic Pension System (UEBPS), which was established in the early 1990s with coverage gradually expanded to all employees with formal labor contracts, including employees in government departments and public institutions and workers in enterprises. The program is funded with a pay-as-you-go social pooling plus funded individual accounts. Social pooling is made up by employers contributing a maximum of $16 \%$ and individuals $8 \%$ of the wage. A worker reaching retirement age (60 for men and 55 for women) after contributing 15 years gets a monthly basic pension from the social pooling equivalent to $20 \%$ of the average wage and a monthly payment equivalent to the funds in the individual account divided by 139 (life expectancy at age 60). In 2019, UEBPS covered about 435 million participants with over 123 million retirees. ${ }^{17}$

The Residents Basic Pension System (RBPS) covers other people who are not covered by UEBPS. The scheme was first established for rural residents in 2009 and then for urban residents in 2011, which is funded by government subsidies and individual contributions. Twelve levels of individual contributions

15 N. K. Song and H. Shin. 2009. A Study on the Social Assistance Delivery Systems in South Korea and Britain. http://www.umdc ipe.org/conferences/policy_exchanges/conf_papers/Papers/1071.pdf.

16 OECD. 2019. Pensions at a Glance 2019: Country Profile-Japan. http://www.oecd.org/els/public-pensions/PAG2019country-profile-japan.pdf.

17 Ministry of Human Resources and Social Security (MOHRSS). 2020. Statistical Communique for Development of Human Resources and Social Security in 2019. http://www.mohrss.gov.cn/SYrlzyhshbzb/zwgk/szrs/tjgb/202006/W02020060853 4647988832.pdf. 
ranging from an annual amount of CNY100 to CNY2,000 were set for participants to select one of them for contribution. Benefits also include two tiers, a basic pension and individual account pension. Funding of the basic pension is shared by the central and local governments. The central government determines the minimum amount of subsidies on an annual basis, while local governments can raise the level of subsidies on their own. Individual contributions and part of the subsidies contributed by local governments go into the individual accounts, while subsidies from the central government and part of the local government subsidies make up the basic pension. A participant reaching age 60 after contributing for 15 years would receive a fixed amount from the basic pension and a monthly sum equal to 1/139 of the total funds accumulated in the individual account. This has also led to wide disparities in the amount of both basic pension and individual account pension across the country. A special feature of the scheme is that all old people are eligible for the basic pension regardless of whether they have contributed to the scheme, which makes it operate like social pensions. By the end of 2019, RBPS enrolled about 533 million participants, with 160 million people receiving benefits. ${ }^{18}$

In 2019, PRC had a total number of 283 million pensioners, about 57\% drawing pension from RBPS and $43 \%$ from UEBPS. Being provincially unified schemes, pension benefits vary markedly across schemes and provinces. Nationally, in 2016, the monthly pension for retirees of enterprises averaged CNY2,362, while those from RBPS averaged CNY105 for the basic pension. ${ }^{19}$

\section{The People's Republic of China's Experience in Social Assistance}

The PRC's social assistance system provides a variety of means-tested cash and/or in-kind benefits for low-income and poverty-stricken households, covering basic living, medical care, education, housing and employment, among others. Among them, three programs are eligible by the elderly and their families: Assistance for People with Special Difficulties (APSD), Minimum Living Standard Guarantee Scheme (Dibao), and Allowances for the Senior Elderly (see last paragraph of this section).

The APSD provides cash benefits and care services to old people without family caregivers and sources of income. It originated from two social assistance schemes established in the 1950s for rural "Five Guarantees" and urban "Three Nos." Following the 2014 State Council Interim Regulations on Social Assistance, the two schemes were merged into APSD, while Five Guarantees and Three Nos were also combined into People with Special Difficulties (PSD). Eligible people include orphans below 16 years old, and the elderly who are unable to provide for themselves through labor and cannot avail the support of family caregivers. Benefits include cash assistance and care services. Depending upon the physical conditions of the elderly, PSD can be provided either through cash assistance if they live in their own homes; or by placing them in a public residential care facility established specially for PSD in townships and street offices, which is an extension of the district government in the urban area. In 2017, about 4.7 million rural and 0.3 million urban elderly received Assistance for People with Special Difficulties (APSD). Meanwhile, 2.2 million urban (17.4\%) and 15.6 million rural (38.6\%) elderly received Dibao benefits (out of 7.42 million urban and 22.49 million rural Dibao beneficiaries). ${ }^{20}$ This amounts to 22.7 million elderly living in poverty, or $9 \%$ of the population over 60 years old. By the end of 2018, APSD covered 4.55 million rural and 0.277 million urban elderly. ${ }^{21}$

18 Footnote 18.

19 MOHRSS. 2017. Reform and Development of Social Insurance System has Achieved Outstanding Progress. http://www .mohrss.gov.cn/SYrlzyhshbzb/dongtaixinwen/buneiyaowen/201705/t20170525_271399.html (accessed April 2020).

20 MOCA. 2018. Statistical Communiqué of Social Service Development in 2017, http://www.mca.gov.cn/article/sj/tigb/2017/ 201708021607.pdf.

21 MOCA. 2019. Statistical Communiqué of Social Service Development in 2018. http://images3.mca.gov.cn/www2017/file/ 201908/1565920301578.pdf. 
Dibao provides cash benefits for households with per capita income below the locally determined assistance threshold. A household is defined based on the household registration system and the resource unit for eligibility test is based on legally defined roles of family members for mutual support specified by the Marriage Law in 2001. The incomes of adult children are also counted in determining the eligibility of their aged parents, regardless of household registration or living arrangements. In 2019, the program covered 8.6 million urban and 34.6 million rural people. Nationally, the assistance averaged CNY624 per person per month for urban residents and CNY5,335.5 per person per year for rural recipients. In 2019, the consumption expenditure was about CNY2,339 per person per month for urban residents (about 27\% of their consumption expenditure) and CNY1,111 for rural residents (40\%). From 2008 to 2010, around $15 \%$ of Dibao recipients were old people. ${ }^{22}$

Allowances for the senior elderly began to be implemented in several municipalities around the turn of 20th century (e.g., Tianjin in 1999) and was nationally adopted by 2016. In most places, the program provides a monthly fixed amount of cash benefits for old people aged above 80 years, which are paid either as a universal benefit such as in Beijing where a monthly CNY100 is paid to the elderly aged 9099, and CNY200 to those aged 100 above; or in the form of Dibao given to low-income households such as in Fujian where all old people aged 80 or above are given a monthly amount of CNY100. ${ }^{23}$

\section{DEVELOPMENT OF THE ELDERLY CARE SYSTEM}

\section{A. The Three-Tiered System}

As early as in 2000, the central government began to explore the establishment of an elderly care system consisting of home- and community-based care (HCBC) and residential care. ${ }^{24}$ This was developed into a three-tier system defined in the Twelfth Five-Year Plan, 2011-2015 as "home-based care as core support, community-based care as necessary support, and residential care as supplementary support". ${ }^{25}$ The Twelfth Five-Year Plan also set specific targets for the three-tiered system: (i) the size of residential care beds would reach 30 per 1,000 elderly; ${ }^{26}$ (ii) home-based care should cover all urban communities, $80 \%$ of rural townships, and $50 \%$ of villages; and (iii) the development of community-based care, which includes daycare centers and other types of community-based elderly care services, should be strengthened.

The targets were restated in the 2013 State Council "Opinions on Speeding up Development of Elderly Care Services", which were to achieve 30-40 residential care beds per 1,000 elderly; and coverage of homebased care in all urban communities, $90 \%$ of townships, and $60 \%$ of villages by $2020 .{ }^{27}$ The Thirteenth

22 MOCA. Various years. Statistical Communiqué of Social Service Development. http://www.mca.gov.cn/article/sj/tjgb/ (accessed April 2020).

23 Source: MOCA.

24 The Party Central Committee and State Council. 2000. Decisions on Strengthening the Work of Aging. http://wenku .baidu.com/link? url=hdwlrh7ndTWLPIbC7otbEGVyzR0mN6EHu5MiLZc15DLdr-irh3KfEPiK3p0HmoDRu1INsQUtP OBFV_OCKwG_duBTiR_r_CdYQq4YRdF6laG.

25 State Council. 2011. Twelfth Five-Year Plan for Developing Elderly Service Undertakings. http://www.gov.cn/zhengce/ content/2011-09/23/content_6338.htm.

26 In operation, the proposed scale of residential care beds is based on a widely used national formula of 90:7:3 or 90:6:4$90 \%$ of the elderly to be cared for at home, $6 \%-7 \%$ in the community, and $4 \%-3 \%$ in residential care settings.

27 State Council. 2013. "Several Opinions of the State Council on Accelerating the Development of the Elderly Service Industry." http://www.gov.cn/zhengce/content/2013-09/13/content_7213.htm (accessed April 2020). 
Five-Year Plan, 2016-2020 continued with the three-tiered system and merged "home-based care" and "community-based care" into "home and community-based care". ${ }^{28}$ In addition, it promoted the establishment of an integrated health and elderly care system and strengthened involvement of the private sector in investing in elderly care services. As such, the building of an elderly care system consisting of residential care and $\mathrm{HCBC}$ with integrated medical and care and a pluralistic delivery system has been the major theme guiding the development of elderly care services in the PRC.

\section{B. Residential Care}

Residential care in the PRC refers to round-the-clock elderly care services provided by a residential facility for the elderly residing in the facility. Apart from boarding services, a residential care facility typically provides health and care services and other support depending on the need of residents. Since the early 1990s, the major efforts of the government have been focused on developing and reforming residential care facilities. Before the 1990 s, almost all residential care facilities were publicly run, which provided care to old people living on social welfare free of charge, including the Three Nos and Five Guarantees. Starting in the early 1990s, public welfare institutions could generate income by providing services to self-paying people. This led to rapid increases in the number of self-paying elderly in public residential care facilities, which has become the majority of residents in residential care facilities.

Since the early 2010s, the central government has issued a series of policies to reform public residential care facilities and promote private involvement in delivering elderly care service. ${ }^{29}$ This has transformed many public residential care facilities into various modes of operation, including three general forms: public (government-funded and operated); publicly funded and privately operated; and nongovernment facilities (funded and operated by the private sector, public institutions, communities, etc.). In 2019, among the residential care facilities registered with civil affairs, the number of nongovernment residential care facilities accounted for about $40 \%$ and residential care beds $45 \%$ of the total. ${ }^{30}$ The role of public residential care facilities was defined as a safety net for the indigent poor, which are required to prioritize dependent or semi-dependent elderly with financial difficulties for receiving services. ${ }^{31}$

Public residential care facilities include social welfare institutions in the cities and homes for the aged in the countryside. Social welfare institutions in the cities provide care of the Three Nos while also accepting fee-paying elderly, while homes for the aged take care of Five Guarantees households. Publicly funded and privately operated facilities accept both social welfare recipients and self-paying elderly, while private residential care facilities are expected to accept mainly self-paying elderly.

Meanwhile, along with reform of the public residential care facilities, the government has also made increasing efforts to "deregulate, monitor and support" the private sector in investing or engaging in the delivery of elderly care services. These measures have led to rapid development of residential care facilities. Between 2010 and 2018, the total number of residential care facilities grew from 40,000 to

28 State Council. 2017. Thirteenth Five-Year Plan for Developing Elderly Service Undertakings and Establishing Elderly Care System. http://www.gov.cn/zhengce/content/2017-03/06/content_5173930.htm (accessed April 2020).

29 MOCA. 2013. Notice on Piloting Reforms of Public-run Elderly Care Facilities. http://www.gov.cn/zhengce/2016-05/22/ content_5075644.htm; MOCA and NDRC. 2016. Notice on the Second Round of Piloting Reforms of Public-run Elderly Care Facilities. http://www.gov.cn/xinwen/2016-09/08/content_5106173.htm; State Council. 2016. "Opinions on Fully Liberalizing the Elderly Care Service Market and Upgrading the Quality of Elderly Care Services.” http://www.gov.cn/zhengce/ content/2016-12/23/content_5151747.htm (accessed April 2020).

30 In an MOCA unpublished administrative document, the MOCA classified residential care facilities into three types: facilities funded by civil affairs, homes for PSD in townships or street offices, and nongovernment-funded ones.

31 State Council General Office. 2011. Plan for Building the Elderly Care System (2011-2015), http://www.gov.cn/zhengce/ content/2011-12/27/content_6550.htm; Regulations on Administration of Elderly Care Facilities. http://www.mca.gov.cn/ article/gk/fg/ylfw/201507/20150715848517.shtml (accessed April 2020). 
168,000; residential care beds also increased from 3.15 million to 7.27 million, averaging 29 per thousand old people. ${ }^{32}$ In 2019, a new policy from National Reform and Development Commission (NDRC), Ministry of Civil Affairs (MOCA), and National Health Commission (NHC) encouraged municipalities to collaborate with enterprises in developing residential care facilities, with the central government providing CNY20,000 in subsidies for each bed; and required that all cities should achieve 40 beds per thousand old people. ${ }^{33}$

A 2019 policy of MOCA required all residential care facilities to provide mainly nursing care to functionally or cognitively dependent elderly, as many residential care facilities are unequipped to provide quality nursing care, or are more interested in attracting able-bodied elderly. In addition, public residential care facilities are required to prioritize services for older people with both care needs (functionally or cognitively impaired) and financial difficulties (PSD and Dibao recipients). Other types of residential care facilities are to provide services to those from families with middle or higher incomes. The government also set a target wherein the number of beds for providing nursing care should reach more than $50 \%$ of the total beds in residential care facilities by 2022. In addition, residential care facilities should introduce needs assessment, quality management, and social work services. ${ }^{34}$ In 2019, the State Council issued the "Opinions on Promoting the Development of Elderly Care Services", ${ }^{35}$ which calls for further reforms in the elderly care sector. It required that public facilities should provide services free of charge or at a reduced cost, and empty beds should be made available to those in need. Public facilities that primarily target self-paying clients could consider registering as state-owned enterprises.

\section{Home and Community-Based Care}

Home and community-based care refers to community-based elderly care facilities including mainly daycare centers and home delivery services to support old people living at their own homes. ${ }^{36}$ Although the development of HCBC began to be promoted in the early 2000s and has been emphasized throughout the two five-year plan periods in developing elderly care services, progress has been slow and both supply and utilization of services have been limited.

A major measure in promoting the development of $\mathrm{HCBC}$ has been the recent pilots of $\mathrm{HCBC}$ services that started in 2016 with an annual amount of CNY1 billion from the central government. By 2019, four rounds of pilots have been carried out, covering a total number of 142 cities and districts and townships. ${ }^{37}$ The pilot cities are allowed to use the funds to develop HCBC by the following methods: (i) attracting private involvement in elderly care through purchase of services or establishing various forms of publicprivate partnerships; (ii) supporting residential care facilities to deliver HCBC; (iii) applying "Internet Plus" in HCBC; (iv) training caregivers; (v) improving care quality and monitoring mechanism; (vi) exploring methods of medical and care integration; and (vii) increasing supply of elderly care facilities. ${ }^{38}$ Pilot

32 MOCA. Various years. Statistical Communiqué of Social Service Development. http://www.mca.gov.cn/article/sj/tjgb/ (accessed April 2020).

33 NDRC, MOCA, and NHC. 2019. Implementation Plan for City-Enterprise Collaboration in Developing Elderly Care Services Universally Accessible by All Elderly People (Trial Plan). http://www.gov.cn/zhengce/zhengceku/2019-09/29/5434985/files/ 6d7a6c3ece074931b8ed1305fcf90f61.pdf.

34 MOCA. 2019. “Opinions on Expanding Supply and Promoting Consumption of Elderly Care services.” 政府信息公开 (mca.gov.cn).

35 State Council. 2019. “Opinions on Promoting the Development of Elderly Care Services.” http://www.gov.cn/zhengce/ content/2019-04/16/content_5383270.htm (accessed April 2020).

36 State Council General Office. 2011. Plan for Constructing Elderly Care System (2011-2015). http://www.gov.cn/zhengce/ content/2011-12/27/content_6550.htm (accessed April 2020).

37 MOCA and MOF. 2020. Announcement on Implementing the Fourth Round of Centrally Funded Pilots of HCBC Services Reforms. http://www.mca.gov.cn/article/xw/tzgg/201908/20190800019217.shtml (accessed April 2020).

38 MOCA and Ministry of Finance. 2016. Circular on Piloting of HCBC reforms. http://www.gov.cn/xinwen/2016-07/19/ content_5092825.htm (accessed April 2020). 
localities are expected to serve as demonstrating projects to push forward the development of HCBC nationwide. Between 2015 and 2018, the number of various HCBC facilities increased from 88,000 to $136,000.39$

Along with piloting of HCBC in increasing numbers of cities, in 2019, MOCA set a new goal for 2022, which was that all street offices establish a comprehensive community-based elderly care facility with the capacity to provide both residential care and $\mathrm{HCBC}$ and provide guidance for $\mathrm{HCBC}$, and each community should set up a daycare center to provide services such as care in daily living, meals, emergency help, recreational activities and social support. The document required that over $90 \%$ of urban communities should be covered by such facilities, and rural townships should also make efforts to establish such facilities where conditions allow. ${ }^{40}$

\section{Health and Care Integration}

The integration of medical care and nursing care services has been promoted by the government since the early 2010s. In the early years, large public residential care facilities were encouraged to run clinics to provide medical care for their residents, and community health facilities were asked to provide basic health care such as health management or keeping health files for elderly in communities. ${ }^{41}$ This was followed by requirements for local governments to direct medical care resources into residential care facilities, communities, and families; and explore ways for hospitals to collaborate with residential care facilities and provide home delivery health care services. ${ }^{42} \mathrm{~A}$ major policy was issued by 10 ministries in 2015, ${ }^{43}$ which set a target for 2020: all medical care facilities should set up a green channel for the elderly to receive medical care services and all residential care facilities should make needed medical service accessible for the residents. Several methods were explored for health and care integration: (i) residential care facilities collaborating with medical and health institutions; (ii) residential care facilities setting up medical care services or clinics; and (iii) medical and health institutions extending services to communities and families. ${ }^{44}$ These methods were further promoted in the Thirteenth FiveYear Plan and several government policies. ${ }^{45}$

The 2016 Healthy China 2030 Plan and its implementation plan promoted the idea of active aging and prevention by emphasizing health care extension to communities and families. While the previous measures focused on medical and residential care institutions, the new policy emphasized services to

39 MOCA. Various years. Statistical Communiqué of Social Service Development. http://www.mca.gov.cn/article/sj/tjgb/ (accessed April 2020).

40 MOCA. 2019. "Opinions on Expanding Supply and Promoting Consumption of Elderly Care Services." http://xxgk.mca.gov. cn:8081/new_gips/contentSearch?id=160822 (accessed April 2020).

41 State Council. 2011. Twelfth Five-Year Plan for Developing Elderly Service Undertakings. http://www.gov.cn/zhengce/ content/2011-09/23/content_6338.htm; State Council General Office. 2011. Plan for Building the Elderly Care System (2011-2015). http://www.gov.cn/zhengce/content/2011-12/27/content_6550.htm (accessed April 2020).

42 State Council. 2013. “Opinions on the Speeding up of the Development of Elderly Care Services." http://www.gov.cn/zhengce/ content/2013-09/13/content_7213.htm; State Council. 2013. "Opinions on Promoting the Development of Health Service Industry." http://www.gov.cn/zhengce/content/2013-10/18/content_6067.htm (accessed April 2020).

43 Including National Health and Family Planning Commission (NHFP), Ministry of Civil Affairs (MOCA), National Reform and Development Commission (NDRC), Ministry of Finance, Ministry of Human Resources and Social Security (MOHSS), Land and Resources (LAR), Ministry of Housing and Construction (MOHAC), China National Committee on Aging (CNCA), and Chinese Medicine Administration.

44 State Council. 2015. Circular on Accelerating Medical Care and Nursing Care Integration. http://www.gov.cn/zhengce/ content/2015-11/20/content_10328.htm (accessed November 2019).

45 State Council. 2016. "Opinions on Fully Liberalizing the Elderly Care Service Market and Upgrading the Quality of Elderly Care Services.” http://www.gov.cn/zhengce/content/2016-12/23/content_5151747.htm (accessed September 2019). 
active and independent old people in communities and families, requiring community health centers and family doctors to play a major role in promoting good health for all. ${ }^{46}$

\section{E. Involvement of the Private Sector}

The establishment of a pluralistic elderly care service delivery system by encouraging private investment has been a consistent theme in government policies since the early 2000s. Earlier policies encouraged private capital through preferential policies such as free land allocation, exemption of taxation and fees, lowered prices in the use of utilities ${ }^{47}$ and promotion of public-private partnerships by contracting out public residential care facilities for private operation. ${ }^{48}$ In the early 2010s, population aging was viewed as a market opportunity, and a set of new policies was issued by different ministries to require local government to provide preferential policies to encourage both private and foreign investment in the elderly care sector, and prioritize private capital in constructing new facilities. ${ }^{49}$ The Thirteenth Five-Year Plan promoted more access and involvement of the private sector in the elderly care system, and put a limit to the number of residential care beds provided by public residential care facilities at no more than $50 \%$ of total beds by 2020 . Further, in 2016, the State Council issued a circular for opening the elderly care service market and required local governments to simplify registration procedures and encourage foreign investment in elderly care, putting in place a market pricing mechanism. ${ }^{50}$ The private sector is encouraged to engage in a wide array of elderly care services, ranging from meal service, to home delivery of medical care, to infrastructure building such as home modification and barrier-free reconstruction in communities and rural areas.

The most recent tax concessions for the elderly care sector provided by the government aimed specially to boost $\mathrm{HCBC}$ by reducing the financial burdens of service providers and encouraging private investment in the elderly care sector. A series of financial incentives were offered for providers of $\mathrm{HCBC}$, including (i) revenues from services are exempted from value-added tax, and all providers are eligible for a 10\% deduction in the taxable income; and (ii) real estate or land used for providing services are exempted from deed tax, property tax, land use tax, and various fees such as urban infrastructure supporting fee and real estate registration fee..$^{51}$ In the State Council 2019 "Opinions on Promoting the Development of Elderly Care Services", a set of preferential policies for the private sector was reemphasized, including (i) elderly care facilities can be treated as small and microenterprises in receiving preferential policies; (ii) nonprofit facilities providing daycare, rehabilitation service, nursing care, and meal service would also enjoy reductions in tax and fees and utility bills; and (iii) private elderly care facilities experiencing financial difficulties would be eligible for financial support. ${ }^{52}$

46 The Plan sets a goal of enabling all people to be healthy through four major measures: (i) health care should be prioritized in public policy implementation; (ii) the development of the health care industry should follow the market mechanism; (iii) emphasize the importance of both prevention and cure, focusing on prevention and control; (iv) give special attention to rural areas, to promote equal access to basic public health services and to maintain public welfare. State Council, 2016, “Guidelines for Healthy China 2030", http://www.gov.cn/xinwen/2016-10/25/content_5124174.htm.

47 Ministry of Finance and Bureau of General Revenues. 2000. Notice on Taxation and Fees for Elderly Care Facilities. http:// www.mof.gov.cn/zhuantihuigu/knqzshap/zcwj/200805/t20080519_22542.html (accessed April 2020).

48 MOCA. 2013. Notice on Piloting Reforms of Public-run Elderly Care Facilities. http://www.gov.cn/zhengce/2016-05/22/ content_5075644.htm (accessed April 2020).

49 State Council. 2010. "Opinions on Encouraging and Guiding Private Capital to Enter the Elderly Care Service Industry"; NDRC et al. 2014. Circular on Accelerating the Construction of Health and Elderly Care Projects. http://www.gov.cn/ zhengce/2016-05/22/content_5075605.htm.

50 State Council. 2016. "Opinions on Fully Deregulating the Elderly Care Service Market and Upgrading the Quality of Elderly Care Services.” http://www.gov.cn/zhengce/content/2016-12/23/content_5151747.htm.

51 Ministry of Finance. 2019. Announcement of Preferential Policies on Tax and Fees for Community-based Elderly Care, Childcare, and Household Services. http://szs.mof.gov.cn/zhengwuxinxi/zhengcefabu/201907/t20190704_3291180.html (accessed April 2020).

52 State Council. 2019. “Opinions on Promoting the Development of Elderly Care Services.” http://www.gov.cn/zhengce/ content/2019-04/16/content_5383270.htm (accessed April 2020). 


\section{F. Financing}

Funding for the development and operation of the elderly care system comes mainly from three sources: government revenues, public welfare lottery funds, and social donations. Among them, government revenues have been used mainly to cover the construction and operation of public residential care facilities such as urban social welfare institutions and rural homes of the aged. Funding responsibilities are borne mainly by local governments with occasional central transfers. Public welfare lottery funds include the welfare lottery funds at central and local levels and the central special public welfare lottery funds, which have been used to support public welfare projects in various fields including elderly care services. During the Twelfth Five-Year Plan period, MOCA required $50 \%$ of the welfare lottery funds to be used for elderly care services, which was raised to 55\% in $2019 .{ }^{53}$ Social donations include various government charities such as the China Charity Federation and Social Welfare Foundation, and funds are usually allocated on a project basis. Apart from funding from above sources, preferential policies such as in land use, taxation and fees, and use of utilities have been practiced since the early 1990s, which have been applicable to both public and private facilities.

While public elderly care facilities have been fully funded with government revenues, subsidies have been the major methods in encouraging the private sector to invest in or run elderly care services. Starting from the early 2010s, central government asked local governments to provide subsidies for the construction and operation of private residential care facilities based on either service capacity or utilization, and local governments were given discretion over the method of subsidies based on the local contexts. ${ }^{54}$ Since 2016, a performance-based approach has been used by the central government to determine the level of central transfers for provinces, which include indicators such as (i) average number of beds per thousand elderly people, (ii) percentage of nursing beds in total beds, and (iii) the construction of elderly care facilities in the previous and current year..$^{55}$ In 2018, State Council required that central transfers and funds for infrastructure building should be tilted to provinces and cities with actively enforced policies to support the development of the elderly care sector and have achieved significant results. ${ }^{56}$ According to implementation methods issued by NDRC in 2020, a total number of 10 provinces nationwide with best practices in the development of the elderly care system will be selected based on performance to receive a $5 \%$ increase in the central budget the following year. Another six provinces will be recognized for best performance on four indicators:

(i) number of the dependent elderly receiving residential care as a percentage of the total number of beds in residential care facilities;

(ii) number of HCBC facilities (including daycare centers and activity centers for the aged) as a percentage of the total number of rural and urban residents' committees;

(iii) number of homes for the aged (which provide residential care for people with special difficulties) in the countryside being registered as a percentage of the total number of such facilities; and

(iv) number of residential care facilities that have passed safety inspection as a percentage in the total number of residential care facilities).

These six provinces will receive favorable allocation of funds from the central welfare lottery funds. ${ }^{57}$

53 Footnote 52.

54 State Council. 2010. "Opinions on Encouraging and Guiding Private Capital to Enter the Elderly Care Service Industry”; MOCA. 2012. "Opinions on Implementing Policies for Encouraging and Guiding Private Capital to Enter the Elderly Care Service Industry." http://www.gov.cn/zhengce/2016-05/22/content_5075659.htm (accessed April 2020).

55 NDRC. 2016. Circular on Methods of Providing Central Subsidies for Supporting Elderly Care Development. http://www .gov.cn/xinwen/2016-12/30/content_5154994.htm (accessed April 2020).

56 State Council. 2018. Circular on Increasing Incentives and Support for Localities which Have Worked Hard and Have Achieved Significant Results. http://www.gov.cn/zhengce/content/2018-12/10/content_5347465.htm.

57 NDRC. 2020. Methods for Implementing Central Subsidies for Encouraging Development of the Elderly Care System. https:// www.ndrc.gov.cn/xxgk/zcfb/tz/202002/P020200221534030261563.pdf. 
Local governments have also followed the performance-based strategy and developed various schemes in providing subsidies to their elderly care facilities. The subsidies are funded mainly by the local governments, usually shared between municipal and district or county governments, while transfers from the central government are also increasingly available. In general, subsidies in construction and operation of elderly care facilities are generally provided in most provinces and cities, while other types of subsidies are also provided in some localities with varying designs. Table 1 shows examples of two local governments providing subsidies for elderly care facilities.

\section{Table 1: Subsidies for Private Elderly Care Facilities in Hangzhou and Wuhan, 2018}

\begin{tabular}{|c|c|c|}
\hline \multirow[b]{2}{*}{ Subsidies } & \multicolumn{2}{|l|}{ Cities } \\
\hline & Hangzhou & Wuhan \\
\hline \multicolumn{3}{|l|}{ Residential care facilities } \\
\hline Construction (lump sum) & $\begin{array}{l}\text { CNY5,000-CNY12,000/per bed for nonprofit } \\
\text { facilities depending on location and property type } \\
\text { (rental or owned); } 80 \% \text { of the above rate for for- } \\
\text { profit facilities; additional subsidies of CNY1,000- } \\
\text { CNY4,000 for facilities with nursing care beds } \\
\text { depending on property type and location; } 20 \% \\
\text { increase in budget for new public facilities approved } \\
\text { for establishment (maximum of CNY3 million). }\end{array}$ & $\begin{array}{l}\text { CNY5,000-CNY8,000/per bed for } \\
\text { non-profit facilities depending on } \\
\text { property type (rental or owned); same } \\
\text { rates for for-profit facilities and rural } \\
\text { welfare homes (public) if they admit } \\
\text { and provide care to dependent elders. }\end{array}$ \\
\hline Operation (monthly) & $\begin{array}{l}\text { CNY200 for each independent elderly over } 80 \text { and } \\
\text { CNY600 for each dependent elderly receiving care. }\end{array}$ & $\begin{array}{l}\text { CNY200 for each independent, and } \\
\text { CNY300 for each dependent elderly } \\
\text { receiving care. }\end{array}$ \\
\hline \multicolumn{3}{|c|}{ HCBC facilities (including rural and urban elderly care service centers daycare centers, and care stations) } \\
\hline Construction (Lump sum) & $\begin{array}{l}\text { Subsidies such as for daycare centers, meal } \\
\text { services, and other services are provided by district }\end{array}$ & $\begin{array}{l}\text { CNY30,000-CNY150,000 for } \\
\text { different types of facilities }\end{array}$ \\
\hline Operation (annually) & $\begin{array}{l}\text { governments, which are based on scores on } \\
\text { performances. }\end{array}$ & $\begin{array}{l}\text { CNY20,000-CNY100,000 for } \\
\text { different types of facilities }\end{array}$ \\
\hline \multicolumn{3}{|l|}{ Other subsidies } \\
\hline & $\begin{array}{l}\text { CNY100,000-CNY150,000 in lump for facilities } \\
\text { running medical services depending on scale of } \\
\text { medical service; CNY10,000-CNY50,000 for } \\
\text { private facilities being ranked above } 3 \text { stars in the } \\
\text { star classification system ( } 1-5 \text { stars); subsidies for } \\
\text { coverage of elderly care facilities by insurance for } \\
\text { contingencies }\end{array}$ & $\begin{array}{l}\text { Lump sum of CNY200,000 for brand } \\
\text { building for chain operators with } \\
\text { more than } 10 \text { facilities; lump sum of } \\
\text { CNY0.5-CNY1 million in construction } \\
\text { subsidies for elderly care operating } \\
\text { within communities (community- } \\
\text { embedded elderly care) }\end{array}$ \\
\hline
\end{tabular}

$\mathrm{CNY}=$ yuan, $\mathrm{HCBC}=$ home- and community-based care.

Note: \$1 = CNY6.62 annual average exchange rate for 2018 (CEIC China Premium Database, accessed 23 April 2021)

Sources: Hangzhou Municipal Civil Affairs Bureau and Hangzhou Municipal Finance Bureau. 2019. Methods for Implementing Subsidies for Elderly Care Services in Hangzhou. http://www.hangzhou.gov.cn/art/2019/4/1/art_1636467_4550.html; Wuhan Municipal Civil Affairs. 2017. “Opinions on Increasing Supply of and Speeding up Elderly Care Services.”市人民政府关于提升养老服务供给水平加快发 展养老服务业的实施意见一武汉市民政局 (wuhan.gov.cn)

On the demand side, since 2014 cash subsidies have been provided to the elderly with both care needs and financial difficulty for receiving elderly care service. ${ }^{58}$ As local governments are responsible for funding the subsidies, eligibility and level of subsidy vary markedly across provinces and cities. In 2018, about 6 million old people received subsidies for elderly care services. ${ }^{59}$ Compared with subsidies for

58 Ministry of Finance, MOCA, and CNCA. 2014. Circular on Providing Subsidies for Old People with Advanced Age and Financial Difficulties. http://www.gov.cn/xinwen/2014-10/23/content_2769678.htm (accessed April 2020).

59 MOCA. 2019. Statistical Communiqué of Social Service Development in 2018. http://images3.mca.gov.cn/www2017/file/ 201908/1565920301578.pdf. 
the supply side, subsidies for old people using services are limited in both scope and levels of subsidies. Table 2 provides two examples of municipalities providing subsidies for service users.

Table 2: Subsidies for Elderly Care Service Users in Chengdu and Wuhan

\begin{tabular}{lll}
\hline & \multicolumn{1}{c}{ Chengdu } & \multicolumn{1}{c}{ Wuhan } \\
\hline Eligibilities & $\begin{array}{l}\text { Elderly people from Dibao or low-income } \\
\text { households }\end{array}$ & $\begin{array}{l}\text { People above } 60 \text { from urban Dibao or low-income } \\
\text { households and those from rural Dibao households if they } \\
\text { are functionally dependent; all people above 80 if they are } \\
\text { from such households; district government are allowed to } \\
\text { expand the subsidies to other people. }\end{array}$ \\
\cline { 2 - 2 } & $\begin{array}{l}\text { Monthly CNY50 for independent elderly; } \\
\text { CNy300-CNY500 for elderly with moderate }\end{array}$ & $\begin{array}{l}\text { Monthly CNY100-CNY800 based on assessed level of } \\
\text { functional ability. }\end{array}$ \\
& $\begin{array}{l}\text { and severe disability; additional CNY200 if } \\
\text { moving to live in residential care. }\end{array}$ & \\
\hline
\end{tabular}

Sources: Chengdu Municipality: Bureau of Finance and Bureau of Civil Affairs. 2016. Methods of Managing Basic Elderly Care Service Subsidies for Old People with Financial Difficulties and for Nursing Care Subsidies for Dependent and Semi-dependent Old People with Financial Difficulties in Chengdu, 关于印发《成都市经济困难老年人基本养老服务补贴及经济困难失能半失能老年人护理补 贴专项资金管理办法》的通知（成财社〔2016〕216号） (chengdu.gov.cn); Wuhan Municipality: Bureau of Civil Affairs and Bureau of Finance. 2018. Circular on Implementing Subsidies for Elderly Care Services for Old People with Special Difficulties in Wuhan, P020210427722271885064.pdf (wuhan.gov.cn)

Meanwhile, starting from 2016, long-term care insurance ( $\mathrm{LTCl}$ ) was piloted in 15 cities from 14 provinces or provincial-level municipalities. According to the "Guiding Opinions on Piloting Long-Term Care Insurance", 60 the pilots aimed to achieve two objectives: (i) explore the establishment of a social insurance system in financing elderly care service and accumulating experience in developing LTCI policies for implementation in the 13th Five-Year Plan period (2016-2020); and (ii) explore policies relating to the scope of $\mathrm{LTCl}$ coverage, premiums and benefit payment, and develop management tools such as needs assessment and quality management of care services.

While local governments were given discretion in designing and implementing their own schemes based on the local contexts, the Guiding Opinions laid out some key policy parameters regarding the care services to be covered, target population to be insured, financing mechanism, and benefits. In main, the piloting $\mathrm{LTCl}$ was intended to operate with a close link with or as a different benefit tier of the Employee Basic Medical Insurance (EBMI). ${ }^{61}$ Specifically, (i) LTCI benefits should cover cost for basic care in daily living and related medical and nursing care of the insured, which are to be paid in proportion to the assessed levels of care needs, with a maximum ceiling of $70 \%$ of the costs; (ii) in the pilot phase, the scheme should cover mainly those enrolled in the EBMI and may gradually expand coverage based on the local circumstances and funding; (iii) a multichannel financing mechanism is allowed to be explored, including making adjustments in the structure of funding in social pooling and individual accounts

60 MHSS. 2016. “Guiding Opinions on Piloting of Long-Term Care Insurances.” http://www.gov.cn/xinwen/2016-07/08/ content_5089283.htm (accessed April 2020).

61 The PRC has two basic medical care insurance systems: Employees' Basic Medical Insurance System (EBMI), which covers workers in government departments, public institutions, and enterprises; and Residents' Basic Medical Insurance System (RBMI), which covers people outside the formal workplace. RBMI was set up first for rural residents in 2003 as the New Rural Corporative Medical System, and in 2010 as the Urban Residents Basic Medical Insurance System. The latter was combined into RBMI in 2016 with a unified funding and reimbursement method. EBMI is funded by employer and employee contributions, while RBMCl by government subsidies and individual contributions, both increasing annually over the years. By 2018, the two schemes insured 1.35 billion participants, covering over $95 \%$ of the population. Among them, EBMI covered 317 million participants, including 233 million employees and 84 million retirees. RBMI covered 897 million people. In 2018, the reimbursement rate for inpatient care reached $80 \%$ of the medical costs for participants of EBMI and $70 \%$ for those covered by $\mathrm{RBMCl}$. In 2019, the reimbursement rate was reported at around $75.6 \%$ of total EBMI medical care costs, and $59.7 \%$ of total inpatient costs through RBMI. 
of EBMI, transferring the surplus of EBMI funds, and adjusting the contribution rates of employees' premiums for EBMI coverage. ${ }^{62}$

By the end of 2018, all pilot cities issued local policies and implemented the program. According to the policies of the piloting cities, wide diversity is found across localities in terms of sources of funding, eligibilities, and provision of benefits. In May 2020, the NHSA decided to expand the pilots to another 14 cities and districts and issued a new document inviting comments from various sectors. Main changes included the following: (i) LTCl will be implemented as an independent insurance system (the sixth insurance program) separate from medical care insurance; (ii) individuals will contribute a portion of their wages as premiums for coverage, and employers will make contributions based on the wage of employees, of which the beginning contribution can be made by transferring part of the premiums employers have paid into the EBMI funding pool; and (iii) benefits will be paid mainly to the insured with severe impairments lasting for over 6 months. ${ }^{63}$

In sum, since the strategy of establishing a pluralistic and three-tiered elderly care system was adopted by the government to meet the care needs of a rapidly aging population, the major efforts of government have been focused on increasing supply of elderly care services by promoting private involvement through preferential treatment and subsidies, and, on the demand side, ensuring that care for the most destitute is guaranteed through means-tested schemes. As such, while the government has been increasing financial incentives for service providers, subsidies on the demand side are limited in both the scope and levels. For most of the elderly with care needs, access to formal elderly care services depends largely on the ability to pay.

\section{PERFORMANCE OF THE ELDERLY CARE SYSTEM ${ }^{64}$}

\section{A. Current Demand for Residential Care is Low}

In 2019, the country's bed occupancy rate in residential care facilities registered under civil affairs averaged about $50 \%$, with most provinces falling between $40 \%-60 \% .{ }^{65}$ Similar rates have been found in several prefectural cities and districts: 62\% in Xiangyang Municipality, Hubei Province; 54\% in Hezhou Municipality of Guangxi Zhuang Autonomous Region; 49\% in Yiling district of Yichang Municipality, Hubei; and 57\% in Yanshan Area of Beijing.

Several factors have accounted for the low utilization of residential care. Firstly, as most of the current elderly have more than two adult children, informal care is still available for those with care needs. One study in Yichang Municipality revealed that $67 \%$ of residents had moved into residential care facilities due to either having no family caregiver, or family caregivers were unavailable to provide care. The same

62 MHSS. 2016. "Guiding Opinions on Piloting of Long-Term Care Insurances.” http://www.gov.cn/xinwen/2016-07/08/content _5089283.htm (accessed April 2020).

63 NHSA. 2020. "Guiding Opinions on Expanding Piloting of Long-Term Care Insurances" (draft for comments). http://xw .sinoins.com/2020-05/06/content_342000.htm (accessed April 2020).

64 This section is based mainly on unpublished reports from studies conducted by the author either as consultant of technical assistance projects of the Asian Development Bank; or as principal researcher in research projects in Beijing Normal University. The cities include Yichang and Xiangyang municipality of Hubei, Yilin District of Yichang Municipality, Yibin Municipality of Sichuan, Nanning and Hezhou municipality of Guangxi Zhuang Autonomous Region, and Yanshan Area of Beijing.

65 MOCA. 2020. A compilation of national elderly care documents. Unpublished. Beijing. 
studies also show that around $96 \%-99 \%$ of the current elderly aged over 65 have at least one adult child, and over half have more than three adult children usually with one or two of them living in the same city or community. Combined with the fact that old people generally have a strong preference for living at home with care by family caregivers, moving into a residential care facility is often the last alternative of the current elderly with care needs.

Secondly, affordability is a major issue constraining access to elderly care, which depends on the ability to pay. As pension incomes of old people are low relative to residential care fees, most of them cannot afford the costs except those eligible for government care subsidies. In Beijing, one of richest cities in the PRC, pensions in 2017 averaged about CNY3,800 for retirees from enterprises and CNY610 for those drawing pensions from RBPS, which is five times the national average. However, residential care fees in private residential care facilities in Beijing ranged from CNY3,500 to over CNY10,000. In most cities, residential care fees are well beyond the affordability of the elderly particularly for those drawing pension from RBPS. In Xiangyang Municipality of Hubei, for instance, in 2019, the monthly private residential care fees ranged from CNY1,000 to CNY3,000 for independent; CNY1,500-CNY4,000 for semi-dependent; and CNY2,500-CNY5,000 for dependent elders. Pension benefits were CNY4,500 for retirees from government agencies and public institutions; CNY2,500 for those from enterprises; and CNY130 for pensioners from RBPS. ${ }^{66}$ In Nanning, the capital city of Guangxi Zhuang Autonomous Region, in 2018, monthly residential care fee averaged CNY2,000 for able-bodied; CNY2,500 for semidependent; and CNY3,000 for dependent older persons. Meanwhile, 70\% of the elderly had a monthly pension below CNY3,000; 25\% below CNY2,000; and 10\% below CNY1,000.

Affordability of elderly care services is further negatively affected by medical care costs, which are insufficiently covered by the current medical insurance systems. As both the Employees' Basic Medical Insurance System and Residents' Basic Medical Insurance System reimburse mainly inpatient care costs and medicine costs for a limited number of chronical diseases, old people still need to bear a considerable share of medical care costs. Studies in the above localities show that medical costs are a major burden for many elderly people and their families, who usually spend a large share of their incomes in purchasing medicine or seeking medical care services. Obviously, many old people will be unable to afford residential care costs without other sources of incomes such as family support or government subsidies.

Internationally, long-term care services would be not affordable for most of the elderly people with care needs and low-income levels even in developed countries if users of services are to bear the full costs. The main sources of financing for long-term care service in countries of the Organisation for Economic Co-operation and Development (OECD) include general taxation (e.g., Nordic countries); LTCI (e.g., Germany, Japan, the ROK, and the Netherlands); and means-tested social assistance (e.g., England, New Zealand, and the United States). ${ }^{67}$ For instance, in the United States, the average annual cost for long-term care services is about $\$ 140,000$. While the rich people may afford the services through out-of-pocket money and the poor is assisted through Medicaid coverage, a large portion of people in between may have financial difficulties in meeting their long-term care needs. ${ }^{68}$ In the PRC, while most of the current elderly can rely on unpaid family caregivers or financial support by children to meet their care needs, it is recognized that the provision of informal care for old people by family members would be a less feasible option for the cohort born after the 1950s due to the single-child family policy. This implies that the government needs to play a more active role in financing.

Thirdly, lack of facilities with both quality care and affordable fees has also been a deterring factor for old people to use residential care. While high-end residential care facilities with quality care and

66 Source: Human Resources and Social Security, Xiangyang Municipality.

67 F. Colombo et al. 2011. Help Wanted? Providing and Paying for Long-Term Care. Paris: OECD.

68 M. K. Gusmano and I. B. Grafova. 2018. Financing Long-Term Care. Affairs. 2 (3). https://americanaffairsjournal.org/2018/ 08/financing-long-term-care/. 
good amenities are not an option for most old people of middle and low incomes, those with low fees usually cannot provide care acceptable for many old people. Public residential care facilities, particularly social welfare institutions above the prefectural level, can usually provide quality care with low fees due to subsidies by government, which often have a long waiting list, while private facilities often charge a higher fee for similar level of care. For most residential care providers, either public or private, cost containment is a major concern of management, which often leads to compromise in quality of care. Findings in several cities show that old people generally have a negative attitude toward residential care and are even apprehensive of moving into such a place, citing disadvantages such as poor meals, lack of individualized services, inconvenience for children to visit them, or incidents of poor services that they learned from TV or friends. Many family caregivers also worry that their elderly parents may not receive adequate care in a residential care facility with affordable fees. Affordability and quality of care has been a vicious circle impeding the development of residential care: high quality would inevitably lead to higher fees while affordable fees are always associated with low quality of care.

Finally, current residential care facilities, both public and private, provide care for a considerable portion of the elderly with low care needs and are not optimally utilized. In Yichang, around 13\%-25\% of current residents in facilities may need the level of care provided by a residential care facility based on standardized assessment instruments. In Xiangyang, over $40 \%$ of current residents are independent and $30 \%$ are semi-dependent. If HCBC services are available, these old people may not need to move into the institutions.

\section{B. Home- and Community-Based Care is Generally Underdeveloped}

Home- and community-based facilities with daycare centers and home delivery service stations have been set up in most urban and rural communities, which operate mostly as public-funded and privately operated units. These facilities were designed with various functions such as daycare, convenient stores, and home delivery service, but in most localities, they serve mainly as activity centers for the elderly free of charge, and to provide limited care service. In recent years, social work services have also been introduced in many communities through government purchase of services.

Studies show that utilization of HCBC services is generally low. Amenities for cultural and recreational activities free of charge are the most frequently used services, and few old people had ever used HCBC such as daycare or home-delivered personal care or housekeeping services. Usually, only recipients of Dibao or old people with special difficulties would use HCBC up to the amount paid by the government. For most other elderly with care needs, elderly care is a choice between care at home by a spouse or children, or moving into a residential care facility. HCBC services were mostly contracted out to nonprofit or for-profit organizations. Although the services charge below-market value fees, old people's willingness to pay for $\mathrm{HCBC}$ is very low. 


\section{KEY POLICY RECOMMENDATIONS}

\section{A. Improve the Elderly Care System for Better Integration of Residential Care and Home- and Community-Based Care}

The current elderly care system needs improvement for integrated and balanced development of HCBC and residential care. Specifically, the elderly care system should be designed with clearly defined goals and targets of services based on the principle of "aging in place", with residential care and HCBC serving old people with different levels of care needs. Public residential care facilities above the district or county level should be upgraded and developed with a focus to provide care mainly for the elderly with complex care needs such as those with cognitive impairments or severe disabilities. Along with improvement and increasing availability of HCBC, care needs of the elderly with moderate impairments can usually be met in the family or community settings, leading to general reduction in need for residential care. On the other hand, declining availability of children as family caregivers may increase need for formal elderly care services such as daycare services, respite care, family caregiver training, and others. In either case, demand for residential care would be mainly for treating cases that cannot be effectively dealt with in family and community settings. Care for people with complex needs requires skilled and professional services including medical and rehabilitation services, which can be provided more efficiently in a municipal institution, once equipped with assessment tools, standards, and skilled workforce.

The goal of HCBC is to keep the elderly in their family and community as long as possible through provision of care and preventative services. A well-developed HCBC service system would enable the elderly with impairments below the moderate level to remain at home instead of moving into institutions, which is key to a balanced development of the elderly care system. Specifically, daycare centers at the street office or township level should be able to provide care for old people with moderate impairments either at the facility or through home delivered personal care or other care services. Community-based

elderly care stations can provide mainly meals, housekeeping, or other individualized services that do not need much skilled or professional workforce. The operation of an elderly care system with integrated development of residential care and HCBC requires the enforcement of municipally unified needs assessment and referral system.

\section{B. Increase the Role of Government in Financing}

On the supply side, government subsidies should shift from subsidies for construction or operation of residential care beds to increased payment to workforce in residential care facilities and daycare centers to ensure that qualified nurses and caregivers in the facilities can be employed with adequate wages. Properly implemented, such subsidies can achieve quality of care without raising the service fee for users. Currently, many provinces and cities are implementing subsidies for caregivers with various levels of funding, although most of the subsidies are still of low level. This practice should be strengthened at the sectoral level through central transfers to facilitate the development of elderly care human resources particularly in the economically constrained localities. As discussed earlier, lack of residential care facilities with both quality care and affordable fees has been a deterrent for old people to use residential care. Investment in skilled human resources would not only produce long-term impact on quality of service, but can also lead to effective reduction in the cost of service for providers and fees for users.

On the demand side, a co-payment mechanism between the government and the elderly using elderly care needs to be set up to increase the purchasing power of the elderly and their families for these services. Specifically, a mix of fixed rate and means-tested subsidies schemes should be developed to 
cover all the elderly with care needs. Fixed rate subsidies should be applied universally to all the elderly with assessed care needs who use specified services financed by government regardless of their financial status. Subsidies in such services as daycare, meals, and housekeeping, which are generally valued by the elderly, can work as a strong incentive for them to use HCBC services. This would stimulate a broadbased demand for HCBC service, which is a crucial factor for its development. For old people with financial difficulties such as recipients of Dibao or APSD, and those belonging to low-income families, additional benefits can be provided to enable them to use the services.

For old people using residential care, means-tested cost sharing by government is also necessary to ensure that the middle- and low-income elderly can receive needed care. Currently, APSD recipients are fully funded and Dibao recipients are partially funded by government for residential care. Such subsidies can be expanded to elderly people drawing pensions from RBPS, which are generally low. To contain costs and discourage use of residential care by those whose care needs can be met through $\mathrm{HCBC}$ or the family system, government subsidies should cover part of the costs of specified care services in proportion to their incomes, while users should bear part of the cost of care services and all costs of room, board, and other services that are not publicly financed. For recipients of Dibao or APSD, additional subsidies can be provided as per their financial status. This is in line with the practices of countries with public $\mathrm{LTCl}$ where coinsurance for both residential care and HCBC services is generally required, and with an increasing amount, while poor people are supported through means-tested public assistance to cover the coinsurance. ${ }^{69}$

An adequate public elderly care financing and related payment system with eligibilities based on a mix of universal and means-tested coverage schemes is necessary not only for promoting the development of the elderly care sector, but also for long-term sustainability. This is particularly important in view of the fact that $\mathrm{LTCl}$ will be the main source of financing in the future. As discussed earlier, to a large extent, unaffordability has been a major factor hampering the development of the elderly care sector. This can be improved through some sort of public financing mechanism particularly for use of HCBC services. In this regard, universal coverage is an investment in elderly care, although it may incur costs in the beginning. In the long run, it would save costs in both medical and care costs in addition to many other economic and social returns if the impaired elderly can avail of proper care from the communities. Under an LTCI financing system, while universal access would be enabled, means-tested schemes are still necessary to enable coverage of poor people. While it is at this stage difficult to estimate the amount of an optimal cost share between individuals and government, it is desirable that such a system should be established by starting with coverage of the most basic needs and gradually expanding eligibilities and the type of services covered. Pilots or experiments of different financing models are necessary to assess its possible influence on both the demand and supply side, such as changes in care needs, availability of informal care, and funding, among others.

Finally, in view of wide disparities in the financial capacity across provinces and cities, shared funding by central and local government is necessary to ensure that a minimum level of care is accessible by all the elderly with care needs.

\section{Support Community and Nonprofit Organizations in providing Home- and Community-Based Care}

Home- and community-based care should be viewed and operated as a public benefit undertaking because it not only enhances the quality of life for the elderly, but also contributes to reducing the use of residential care, which is more expensive than $\mathrm{HCBC}$ for both government and family. To make HCBC affordable and accessible by all the elderly and families, government should play a more active role in

69 F. Colombo et al. 2011. Help Wanted? Providing and Paying for Long-Term Care. Paris: OECD. 
financing. Specifically, government should support community and nonprofit organizations to provide basic HCBC services as a public benefit, while also encouraging for-profit organizations to operate individualized or high-end services with subsidies from the government.

Currently, HCBC facilities have been set up in most urban and rural communities. With government bearing the personnel and operational costs, community and nonprofit organizations have the advantage in mobilizing a wide range of social resources and the voluntary sector in providing elderly care with minimal costs for end-users of the service. They can also support and provide organization of mutual support groups among old people and residents to provide elderly care service for those with need, as has been widely practiced in many communities.

In addition, community and nonprofit organizations are also more trusted by the elderly and the general residents. They have the advantage of collaborating with family caregivers. As current old people with care needs are mostly over 75 years old and have several children who are a major source of elderly care services, HCBC administered by community and nonprofit organizations can work in partnership with family caregivers, which may contribute not only to quality of care, but also costs containment once caregivers have the appropriate skills.

\section{Support the Development of Elderly Care Management Tools}

Elderly care service management tools such as needs assessment, financing and payment systems, and a management information system (MIS) should be developed based on research to prepare for the future when care needs are expected to increase dramatically for people currently with one child who would grow into older age. Enforcing a nationally standardized needs assessment mechanism is necessary for government to target elderly care resources at those with actual need. Such a mechanism can screen out those with no care need for elderly care service while ensuring that those with needs receive appropriate services. It is particularly necessary to ensure that subsidized elderly care services are provided to those eligible for the services.

Implementing an MIS is essential for effective operation of the elderly care system. A well-designed and implemented MIS can support many important functions including: (i) screening, identifying, and monitoring care needs of the elderly and their families for proper intervention; (ii) coordinating policies of different government departments and services from different elderly care providers; and (iii) supporting evidence-based policy making in developing the elderly care system. By collecting and updating data systematically on service inputs, processes, outputs, outcomes and quality, MIS can help the government to accumulate experiences in improving elderly care policies such as in developing financing and payment mechanisms; improving needs assessment; collaborating with private providers; and monitoring needs, services, and results.

Currently, care for the aged population is still manageable due to most elderly with care needs having several children to take care of them. As discussed earlier, research and development on these tools are important for government to accumulate knowledge to meet the care needs of old people, which would be increasing dramatically about 10 years hence when parents with only one child grow into advanced age.

\section{E. Strengthen the Role of Street Office or Township Aging Offices}

The design and implementation of an effective elderly care system requires joint efforts from many government departments such as civil affairs, finance, health, human resources and social security, 
education, and elderly care providers. The aging office established in the street office and township is in a better position in coordinating the stakeholders, and should be strengthened to play a major role in leading and overseeing the implementation of the local community-based elderly care system.

Specifically, the aging office should be staffed with workers with expertise in aging, elderly care or other related fields, so that it can perform the following functions: (i) enforcing and overseeing the implementation of laws and policies relating to the elderly population and elderly care; (ii) planning the local elderly care system and overseeing its operation to ensure that proper principles and practices are adopted; (iii) enforcing standards for services and workforce; and (iv) providing guidance and support for communities, families, and the elderly in the operation of the elderly care system. 


\section{Development and Performance of the Elderly Care System in the People's Republic of China}

This paper attempts to understand and provide policy recommendations on the development and performance of the emerging elderly care system in the PRC. The three-tiered elderly system consists of home-based care as the core support, community-based care as necessary support, and residential care as supplementary support. The main policies and progress of the system are explained, including insights on how the government encourages private sector involvement. A key recommendation of this paper is the need for better integration of residential care and home- and community-based care as part of the elderly care system.

\section{About the Asian Development Bank}

ADB is committed to achieving a prosperous, inclusive, resilient, and sustainable Asia and the Pacific, while sustaining its efforts to eradicate extreme poverty. Established in 1966, it is owned by 68 members -49 from the region. Its main instruments for helping its developing member countries are policy dialogue, loans, equity investments, guarantees, grants, and technical assistance.

$\mathrm{ADB}$ 